\title{
Internationalisation, Regionalisation and Localisation: Reflections on Co-habitation in 'the Third Space' in Tertiary Education
}

\begin{abstract}
Summary: The main aim of the paper is to explore the likelihood of tertiary education, at the tertiary level educational institutions in the Caribbean, including University of the West Indies (UWI), making educational gains in 'a third space' where the principles of internationalisation, regionalisation and localisation cohabit. To strengthen the discussion, the paper identifies and briefly explains the global 'scapes' that inspire and sustain intellectual capacity. It next presents an overview of tertiary education in the Caribbean, and it then introduces Henry's (2012) 'internationalisation spirit' and George and Lewis' (2011) 'creation of a third space.' Finally it scrutinizes the interconnectedness of the concepts with regard to 'cohabiting and making educational progress in 'a third space". The paper acknowledges the intricate relationship that exists between internationalisation, regionalisation and localisation; so following the 'Methodology' section, it gives some details about how these are conceptualised within given contexts.
\end{abstract}

Резюме: Главной целью данного исследования является выяснение возможности получения высшего образования в учреждениях региона Карибского моря, в частности, в Университете Вест-Индии (УВИ) и изображение положительных сторон образования, которые имеются 8 «третьем пространстве», там, где сходятся принципы интернационализации, регионализация и локализация. Для усиления настоящей дискуссии данная статья идентифицирует и кратко объясняет глобальные «ландшафты», которые инспирируют и сохраняют интеллектуальные способности. Затем дается обзор высшего образования в регионе Карибского бассейна, $и$ предпринимается попытка введения в "Дух интернационализации» Генри (2012) и 'создание третьего пространства' Джорджа и Льюиса (2011). Наконеи, проверке подвергается структурирование концепций в отношении «прогресса в области образования посредством встречи в третьем пространстве. Статья доказательно обосновывает сложное отношение между интернационализацией, регионализацией и локализацией, и в разделе «Методология» она показывает некоторые детали, как они существуют внутри указанных взаимосвязей.

Zusammenfassung: Hauptziel dieser Untersuchung ist es, die Wahrscheinlichkeit von Hochschulbildung an Einrichtungen in der Karibik, darunter an der University of the West Indies (UWI), zu erkunden und Bildungsgewinne darzustellen, die in "einem dritten Raum" möglich sind, dort, wo Grundsätze der Internationalisierung, Regionalisierung und Lokalisierung zusammentreffen. Um die Diskussion darüber zu verstärken, identifiziert und erklärt dieser Artikel kurz die globalen "Landschaften", die intellektuelle Fähigkeiten inspirieren und erhalten. Dann wird ein Überblick über die Hochschulausbildung in der Karibik gegeben, und es erfolgt eine Einführung in Henry's "Internationalisation Spirit" (2012) und George und Lewis' 'creation of a third space' (2011). Schließlich wird die Vernetzung der Konzepte in Bezug auf "Bildungsfortschritte durch Begegnung in einem dritten Raum" auf den Prüfstand gestellt. Der Artikel belegt die komplizierte Beziehung zwischen Internationalisierung, Regionalisierung und Lokalisierung, und er zeigt im Abschnitt „Methodologie“ einige Details, wie diese innerhalb der gegebenen Zusammenhängen konzipiert sind.

\section{The Methodology}

The paper utilises a literature-based methodological approach. This approach should not be viewed as using the literature as a process of empirical research, but rather as an approach "where existing literature is the population" (Comerasamy, 2012). It is from this 'population' that the researcher gets the all information he/she needs for data-collection and analysis. Unlike the meta-analysis approach that focuses "on data, as reflected by the operationalization of variables, the magnitude of 
effect sizes, and the sample sizes", this 'narrative review' method is of a qualitative nature (King \& He, 2005, p. 670). The area of concern is on the conclusions that are reached from the various studies that researchers have conducted and from other narrative reviews. Still, this literaturebased approach can be used "to build a scientific knowledge base" (Rumrill \& Fitzgerald, 2001, pp.165-170). Employing Rumrill \& Fitzgerald's general guidelines on how this type of research should be conducted, for this paper, having identified the area for research and decided on what should be included, I next selected studies that relate to this area and identified themes that have emerged from the selected studies. I then analysed the selected studies and other narrative reviews and made inferences from them.

Like all other data-collection methods, the literature-based approach has its limitations. Because it is characterised by qualitative design principles, the issue of subjectivity surfaces with regard to determining which studies to select, how they are analysed and how conclusions are drawn. There is also the question of researcher bias because of personal experiences and/or the area of expertise. This can lead to the possibility of making incorrect assertions, or even making erroneous inferences. Rumrill \& Fitzgerald note another problem that can surface - determining and integrating possible complex interactions when a large set of studies is involved (ibid). In carrying out research for this paper, I was mindful of the demerits of the literature-based approach used, and therefore took care to keep them at as low a level as possible.

\section{Conceptual Notions}

Internationalisation, regionalisation and localisation are the key concepts that feature in this paper. Because of their special relationship with globalisation, this concept will also be in focus.

Internationalisation: Over the past decade or so, internationalisation has been linked to, and explained from a Higher Education (HE) perspective (Wang, 2002; Qiang, 2003; Jones \& Brown, 2007; Fielden, 2008). A popular conceptualisation comes from Knight (2004, p. 7) who advances that when universities make a deliberate effort to "integrate an international dimension" into their teaching learning and research activities and service functions, this gives then an international stance. This suggests that universities remain nationalised or localised if they do not integrate international dimensions. But generally, research activities at universities, which include knowledge expansion, do give them an international outlook, however 'small'. It seems then, that it is the extent to which they embrace integration that gives them an internationalised status. Kishun $(2007, \mathrm{p}$. 463) asserts that national or local polices are quite useful "in providing a broad framework within which a higher education sector can strategically develop to take advantage of opportunities to internationalise". Bringing UWI in the frame, as a regional institution, it becomes an imperative for it to be fully regionalised while taking advantage of opportunities to internationalise.

Regionalisation: To take the 'sting' from the task of defining a very complex concept, I begin with explaining what region means in its simplest sense. Geographically, it is a group of countries in the same area, as in the Caribbean Region. Much more involved is regionalisation which Hurrell (2007, p. 4) explains as: the "societal integration and the often undirected process of social and economic interaction". The economic link is instructive as this seems to have given rise to regionalism which is markedly different to regionalisation. Regionalism is "the formal process of intergovernmental collaboration between two or more states" (Ravenhill, 2008, p. 174). The main difference here appears to be in the 'official' and 'unofficial' nature of the interactions. Beeson $(2007$, p. 5) share a similar view by emphasizing that the latter is the set of conscious activities carried out by states within a region to cooperate while the former is a less conscious process which 
is the outcome of these states policies.

To return to the economic link mentioned in the previous paragraph, the 1980 s economic downturn caused Caribbean regional economies to slide into deep recession (Miller, 1992, p. 28). Educational progress was retarded. It was by means of 'Regionalism' that new educational policies and programmes were endorsed and subsequently implemented across the entire Caribbean region (CARICOM Secretariat, 1993, p. 69). Regionalism is defined as:

A way of doing, thinking, feeling, which seeks to identify, give meaning to, acknowledge the integrity of common and unique Caribbean Communities, and also to pool these various experiences obtained from institutions and from persons in order to compel an action (CARICOM Secretariat, 1993, p. 5).

Regionalisation too played a significant part in effecting social and economic interaction throughout the region. The 'new wave of regionalism' that is dominating the nations' agenda is tightly knotted to the "current transformation of the world, especially globalisation" (Söderbaum and Sbragia, 2010, p. 9). This can greatly compromise national and local values and traditions.

Localisation: Explained in layman's terms, to localise is to be converted into local with reference to one's outlook and actions within a specific area. Used in this context, localisation is tied to traditions and culture; so phrases such as 'local food', 'local church' and 'local music' are common expressions in Caribbean societies. 'Native', 'indigenous' and 'national' also represent 'local' where 'local' is a subset of 'national'. It is probably in this sense that 'local' has gained a meaning of its own, outside of academic circles (Jean-Sebastien, 2009; Waters, 1995). And, as George and Lewis (2011, p. 722) point out, "local knowledge" does not get the attention it deserves in on national, regional and international education agendas. The irony here is that particular local activities are often seen as reflections of the overall national purpose. Still, internationalisation, regionalisation and localisation are linked on global levels.

Globalisation: For this paper, to explain globalisation, I borrow a conceptualisation from Maringe, Foskett and Woodfield (2013) who see globalisation as: "a term describing world-scale transformations taking place in the political and ideological, the technical and economic, and the social and cultural aspects of life" (p. 12). Globalisation has positive and negative consequences (Chirico, 2014; Steger, 2003), but either way no nation is immune to its impact because of the power of its 'flows'.

\section{Global 'Scapes'}

Appadurai (1996) identified five 'scapes' - ethnoscape, technoscape, finanscape, mediascape and ideoscape. These are factors that contribute to the global flow of ideas and information. They are not static but continue to evolve to fit the various situations in which they operate. There is an inextricable relationship between the scapes. Ethnoscape has to do with global migratory patterns; technoscapes employ technology to link people of all cultures together; this second scape is closely tied to the economy that goes up and down at will, hence the finanscapes; mediascapes bring about information flows via media outlets such as television, radio and newspaper; and ideoscapes "centre on the ideologies of a government and those that oppose it and is highly dependent on the context of the spectator" (Hogan, 2010). The interaction between the different scapes and the perceptions formed about peoples and global cultures all have serious implications for education activities around the world. 


\section{Tertiary Education}

The focus here is on the Caribbean. Professor Andrew Downes, UWI, explains tertiary education this way: "all post secondary education consisting of a mix of private and public universities, colleges, technical and vocational institutes/colleges/polytechnics and professional schools offering certificates, diplomas and degrees" (Downes, 2013). UWI is the Regional University with four campuses - Mona, Jamaica; Cave Hill, Barbados; St. Augustine, Trinidad and Tobago; and the Open Campus that operates in sixteen countries in the English-speaking Caribbean. This position gives UWI much responsibility in sustaining tertiary education programmes in the Region. An objective of UWI Tertiary Level Institutions Unit (TLIU) is: "to design, procure funds for and manage special projects to address identified tertiary education development needs" (UWI, 2014). Enhancing the capacity of regional TLIUs and managing the processes between them will assist in cultivating an 'internationalisation spirit'.

\section{An 'Internationalisation Spirit'}

The 'internationalisation spirit' is more than establishing international links and partnerships. The goal should be to go beyond what is expected, that is, to meet, and exceed international standards. When this is done then UWI would be in a position to establish an international reputation that is based on quality. But having this reputation is insufficient if UWI should maintain a very high status with regard to international engagement with other universities. What is needed is to saturate the institution with high quality educational activities that have robust international dimensions. This is what having and 'internationalisation spirit' entails (Henry, 2012). Mr. Sharan Chandradath Singh, Director, Office of Institutional Advancement and Internationalisation, UWI, St. Augustine, adopts a similar stance by noting:

Our regional character will be the basis for our international engagement. The UWI is unique in the global setting (its regional reach, its areas of focus, its history, its dominant role in Caribbean society) ... We understand and have embraced this uniqueness and it is on this basis that we will engage the rest of the world to collaborate and compete (cited in Henry, 2012).

To underline its commitment to cultivating 'an internationalisation spirit', UWI established the Office of Regionalisation and Internationalisation (ORI) to oversee international affairs. Dr Fisher, Director of the International Office, sees ORI as "an advocate for the things we need to do to become further internationalised" (cited in Henry, 2012). But how can this attitude facilitate operating within 'a third space'?

\section{The 'Third Space'}

The international, the regional and the local each has special features but each shares a complex interrelationship that is framed by 'cultural hybridity.' Herein lies the 'third space'. George and Lewis (2011, p. 725) assert: "it is in this third space that there are possibilities for the transformation of different strands of knowledge into new hybrid understandings". With reference to education, it is in this 'third space' that indigenous knowledge can gain prominence in institutions' curricula. To cite an example, the primary school Social Studies syllabus has as one of its theme, 'Interdependence of World Peoples'. This can be developed from local, regional and international perspectives, thus providing a 'global' foundation for understanding similar themes at secondary and tertiary levels. The situation provides many educational opportunities for internationalisation, 
regionalisation and localisation to cohabit in 'a third space'.

\section{Concluding Remarks}

The paper considered this question: What are the possibilities for tertiary education in the Caribbean to make educational gains in 'a third space' where the principles of internationalisation, regionalisation and localisation cohabit? Initial impressions from the analysis show that different types of relationships exists between the interacting elements and that the resulting dialectics are just as useful for tertiary education advancement, as the mutual alliances.

The Caribbean is in a unique position where 'small', as far as land mass is concerned, can be used as an advantage. The Caribbean's history with its European colonisers, particularly England, France, Spain and Holland has always kept islanders linked, visibly or invisibly, by an 'international thread' to these countries. Another 'international thread' is attached from the English-speaking Caribbean to the Commonwealth. A similar thread links the Caribbean to North America where funding agencies have played a significant role in its education expansion programmes. Moreover, there are strong ties with Latin America; not in the way that the literature often groups Latin America and the Caribbean together as if they were literally one and the same thing, but historically and geographically (where the common denominator is the shores of the Caribbean Sea). The countries also experience various types of connections made via educational institutions and other regional organisations. Besides, each country has its unique 'local' story.

The introduction of indigenous knowledge into the formal education systems, and aligning it to regional educational activities can only serve to strengthen the case for cultivating an 'internationalisation spirit'. This very framework clearly demonstrates that internationalisation, regionalisation and localisation cohabit in 'a third space' with strong possibilities of making educational advancement.

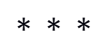

Note: This article is a reversed version of the authour's contribution to: Popov, N.; Wolhuter, C.; Skubic Ermenc; Hilton, G.; Ogunleye, J.; Chigisheva, O. (Eds.): Education's Role in Preparing Globally Competent Citizens. BCES Conference Books. Volume 12. Sofia (Bulgaria): Bulgarian Comparative Education Society, pp. 326-332.

\section{References}

Appadurai, A. (1996): Modernity at Large Cultural Dimensions of Globalization. Minneapolis: University of Minnesota Press.

Beeson, M. (2007): Regionalism and Globalization in East Asia. Basingstoke: Palgrave McMillan. CARICOM Secretariat (1993): The Future of Education in the Caribbean. Georgetown: CARICOM Secretariat.

Chirico, J. (2014): Globalization: Prospects and Problems. London: Sage.

Comerasamy, H. (2012): Literature-based Research Methodology. In: http://www.slideshare.net/huguette_comerasamy/literature-based-research-methodology . Accessed February 2014.

Downes, A. (2013): Financing Tertiary Education in the Caribbean: The Case of the University of the West Indies. In: http://www.caribank.org/uploads/2013/05/The-Case-Study-of-UWI.pdf 
Accessed February 2014.

Elkins, Z. \& Simmons, B. (2005): On Waves Clusters and Diffusion: A Conceptual framework. In: Annals of the American Academy of Political Social Sciences, pp. 598, 33-51.

Fielden, J. (2008): The Practice of Internationalisation: Managing International Activities in UK Universities. London: UK Higher Education Unit.

George, J. \& Lewis, T. (2011): Exploring the Global/Local Boundary in Education in Developing Countries: The Case of the Caribbean. Compare: A Journal of Comparative and International Education, 41(6), pp. 721-734.

Henry, J. (2012) Internationalisation Spirit. In: https://sta.uwi.edu/pelican/features/article1.asp . Accessed February 2014.

Hogan, A. (2010): Appadurai's 5 -scapes. https://www.amherst.edu/academiclife/departments/courses/1011F/MUSI/MUSI-041011F/blog/node/229354 . Accessed February 2014.

Hurrell, A. (2007): One World? Many Worlds? The Place of Regions in the Study of International Society. International Affairs 83(1), pp. 127-146.

Jones, E. \& Brown, S. (Eds.) (2007): Internationalising Higher Education. London: Routledge.

Jean-Sébastien, G. (2009): What is Global and What is Local? A Theoretical Discussion Around Globalization. Parsons Journal for Information Mapping, 1(2), pp. 1-16.

King, W. \& He, J. (2005): Understanding the Role and Methods of Meta-Analysis in IS Research. Communications of the Association for Information Systems, 16 (1), pp. 665-686.

Kishun, R. (2007): The Internationalisation of Higher Education in South Africa: Progress and Challenges. Journal for Studies in Higher Education, 11 (3/4), pp. 455-469.

Knight, J. (2004): Internationalization Remodelled: Definition, Approaches, and Rationales. Journal of Studies in International Education, 8 (1), pp. 5-31.

Maringe, F., Foskett, N. and Woodfield, S. (2013): Emerging Internationalisation Models in an Uneven Global Terrain: Findings from a Global Survey. Compare, 43(1), pp.9-36.

Miller, E. (1992): Education For All: Caribbean Perspectives and Imperatives. Washington D.C.: InterAmerican Development Bank.

Qiang, Z. (2003): Internationalization of Higher Education: Towards a Conceptual Framework. Policy Futures in America, 1(2), pp. 248-270.

Ravenhill, J. (2008): Global Political Economy. Oxford: Oxford University Press.

Rumrill, P. \& Fitzgerald, S. (2001): Speaking of Research: Using Literature Reviews to Build a Scientific Knowledge Base. Work, 16(2), pp. 165-170.

Söderbaum, F. \& Sbragia. A, (2010): EU Studies and the 'New Regionalism': What can be Gained from Dialogue? Journal of European Integration. 32(6), pp. 563-582.

Steger, M. (2003): Globalisation: A Very Short Introduction. Oxford: Oxford University Press. UWI (2014): Tertiary Level Institutions Unit (TLIU). http://www.cavehill.uwi.edu/administration/tliu.asp . Accessed February 2014.

Wang, Y. (2002): Massification, Internationalisation, networking and Corporatisation of Higher Education: International Comparative Perspectives. Beijing: Yunnan University Press.

Waters, M. (1995): Globalization (1st Edition). London: Routledge.

\section{About the Author}

Dr. Gertrude Shotte, lecturer, School of Health and Education, Middlesex University, London, United Kingdom. Contact: g.shotte@mdx.ac.uk 